MAREK TATAR, WARSZAWA

ORCID: 0000-0002-7161-8196

\title{
WSPÓLNOTOWY I WSPÓLNOTOTWÓRCZY CHARAKTER MODLITWY
}

Zagadnienie modlitwy należy zaliczyć do kluczowych na gruncie teologii duchowości katolickiej, ale także w praktycznym wymiarze życia i rozwoju duchowego chrześcijanina. Należy stwierdzić, że jest ona źródłem, środkiem, ale także swoistym probierzem dynamiki jego rozwoju w wierze. Właściwie nie można wskazać żadnej religii, która nie uwzględniałaby tego aspektu. Oczywiście, w całej różnorodności religii, a także wyznań, mamy zróżnicowane rozumienia jej istoty, a także przybiera ona różnorodny wymiar, formy oraz charakter. Jednak zawsze pozostaje niezmiennym fenomenem, ponieważ dotyka relacji człowieka do Boga i jest nie tylko jej wyrazem, ale także ją tworzy oraz rozwija. Chrześcijaństwo podkreśla przede wszystkim charakter relacyjno-personalistyczny modlitwy, co oznacza, że jest ona z jednej strony darem, który człowiek otrzymuje od Boga, a jednocześnie staje się odpowiedzią na Jego inicjatywę. Z tego względu należy przede wszystkim podkreślić jej charakter dialogiczno-wspólnotowy. Fenomen modlitwy domaga się ciągłego przepracowywania go w kontekście kulturowo-cywilizacyjnym. Sama istota modlitwy chrześcijańskiej nie zmienia się, ale mamy do czynienia ze zmianą sposobu jej wyrażania. Warto także stwierdzić, że jej charakter zależy przede wszystkim od etapu rozwoju duchowego człowieka, co zauważają i podkreślają wszyscy teologowie. Jednym z jej wymiarów jest wspólnotowość. Spojrzenie na modlitwę w tym kontekście domaga się pokreślenia zarówno pewnego współczesnego kryzysu rozumienia i przeżywania wspólnotowości, jak również jej niezbędności. Następnie należy zwrócić uwagę na istotę 
tego rodzaju modlitwy, by w konsekwencji ukazać jej praktyczny wymiar.

\section{Zasadnicze rozumienie wspólnoty i wspólnotowości}

Źródłem pochodzenia człowieka jest wspólnota osób Bożych. Przeżywa on swój etap ziemski w społeczności i ostatecznie jego celem jest zjednoczenie z Bogiem Wspólnotą. ${ }^{1}$ Analiza samej struktury człowieka ujawnia jego powołanie do istnienia jako istoty społecznej. Powołanie do istnienia ma zatem charakter wspólnotowy i wspólnoto-twórczy. ${ }^{2}$ Właściwym kluczem do zrozumienia podwójnego wymiaru człowieka, tzn. jego indywidualności, a zarazem wspólnotowości, jest właściwe zdefiniowanie wspólnoty. Sformułowania encyklopedyczne wskazują na wieloaspektowość i złożoność próby zdefiniowania. Określenie, czym jest wspólnota oraz wspólnotowość, zależne jest od dziedziny, która podejmuje tę próbę a także charakterystycznych elementów konstytuujących wspólnotę, które uważa się za zasadnicze ze swojego punktu widzenia. Generalnie, K. Milcarek stwierdza, że samo określenie pochodzi od greckiego terminu

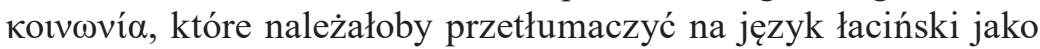

1 Por. H. Urs von B alth a s a r, Teologika. Duch Prawdy, t. 3, tłum. J. Z y c h o w i c z, Kraków 2005, s. 378. „,...natura jest już od zawsze objęta łaską, a czas przyznany stworzeniu jest mu udzielony z odwiecznie trójjedynego czasu i odwiecznie trójjedynych dziejów Boga"; A. S c o 1 a, Osoba ludzka. Antropologia teologiczna, tłum. L. B a 1 t e r, Poznań 2005, s. 56-57; L.F. L a d a r i a, Wprowadzenie do antropologii teologicznej, tłum. A. B a r o n, Kraków 1997, s. 41-44. Autor stwierdza: „Jeżeli Bóg, który zbawia człowieka jest Bogiem Jedynym i Troistym, także Ten, który go stwarza, jest Jedyny i Troisty".

2 Por. KDK 23, 24. Drugi punkt nauki Kościoła bardzo wyraźnie zaznacza: „Bóg, który wszystko otacza ojcowską opieką, ze chciał, by wszyscy ludzie tworzyli jedną rodzinę i odnosili się do siebie nawzajem w duchu braterstwa. Wszyscy bowiem, stworzeni na podobieństwo Boga, który «z jednego człowieka wywiódł cały rodzaj ludzki, aby zamieszkiwał cała powierzchnię ziemi» (Dz 17, 26), powołani są do jednego i tego samego celu, to jest Boga samego". 
communio i communitas oraz congregatio. ${ }^{3}$ Sięgając do łacińskiego słownika, znajdziemy określenie communio jako „wspólny udział, uczestniczenie, wspólnota". ${ }^{4}$ Idąc za próbami sprecyzowania, których dokonuje ks. prof. M. Jagodziński, zauważamy, że należy uwzględnić podwójną konotację metaforyczną, tj. odnoszącą się do rdzenia mun, oznaczającego wołanie gromadzące ludzi nakierowanych na siebie, oraz munus określającego zadanie posługę, dar poczęstunek, wzajemne zobowiązanie służby. Pierwotnie, jak zauważa teolog, opierając się na 1 Kor 10,16 oraz 2 Kor 13,13 , oznaczało ono posiadanie udziału w Jezusie Chrystusie oraz w działaniu Ducha Świętego. ${ }^{5}$

Próba definicji mająca bardzo gruntowne zakorzenienie w Piśmie Świętym prowadzi do teologicznego określenia wspólnoty. Jak twierdzi ks. A. Nadbrzeżny, ,oznacza zjednoczenie osób oparte na autentycznych i głębokich relacjach międzypodmiotowych (communio personarum)". ${ }^{6}$ Ten charakter osoby wynika z jej indywidualnego, a zarazem społecznego charakteru.

Katolickie ujęcie etyczne, opierające się na św. Tomaszu z Akwinu, podkreśla przede wszystkim trwałość zjednoczenia osób, mającego charakter moralny, które przez wspólne działanie zmierza do godziwego celu. Idąc za arystotelesowskim schematem materii i formy, stwierdza się, że materię stanowi wielość osób zaś formę zjednoczenie moralne oparte na ,jedności umysłów, woli i sił”. 7 Z kolei etyk, ks. prof. T. Ślipko, podkreśla przede wszystkim konstytutywny element, którym jest cel, poznany i ukierunkowujący wspólnotę. ${ }^{8}$

3 Por. K. M i l c a re k, Wspólnota, w: Encyklopedia katolicka (dalej: EK), t. XX, Lublin 2014, kol. 999.

4 Hasło: Communio, w: J. K o r p a n t y (red.), Słownik łacińsko-polski, Warszawa 2001, s. 126

5 Por. M. J a g o d z i ń s k i, Sakramenty w stużbie communio, Warszawa 2008, s. 7; R. S k r z y p c z a k, Kościót jako misterium, communio i missio, Warszawskie Studia Teologiczne XVII/2004, s. 175.

6 A. N a d b r z e ż n y, Wspólnota. W teologii, w: EK, kol. 1000.

T. Ś 1 i p k o, Zarys etyki szczegółowej, t. 2, Kraków 1981, s. 122.

8 Por. tamże. 
Na gruncie nauk psychologiczno-społecznych, a szczególnie nauk socjologicznych, rozumie się wspólnotę jako pewną zbiorowość lub grupę społeczną, u podstaw której znajdują się więzi o charakterze wewnętrznym, następnie struktura, z którą identyfikują się przynależący do niej, akceptacja określonej wspólnej hierarchii wartości oraz celów mjących charakter nadrzędny. Takie rozumienie wspólnotowości suponuje związek istniejący między przynależącymi do określonej wspólnoty oparty na podłożu kulturowym, geograficznym, politycznym. W ujęciu socjologicznym człowiek przynależący do wspólnoty podlega procesowi socjalizacji, odwołującemu się co cech i celów danej wspólnoty. Na tym gruncie wyróżnia się następujące kategorie wspólnot: narodowa, rodzinna, wyznaniowa, kulturowa, państwowa, międzypaństwowa, ogólnoludzka. ${ }^{9}$

Psychologia koncentruje się w swoich badaniach przede wszystkim na elementach psychicznych, które uspołeczniają jednostkę, a także wpływach społeczności na sposób integracji psychicznej jednostki. Opracowania dotyczą w dużej mierze tzw. psychologii społecznej. Łączy ona teorie psychologiczne oraz socjologiczne. Dotyka takich zagadnień jak konformizm, etykietowanie, nonkonformizm, charakter grupy (młodzieżowa, zawodowa, akademicka itp.) Akcentuje przede wszystkim takie elementy, jak członkostwo, zasada identyczności, ośrodki skupienia, cele i zadania, struktura grupy. Bardzo ważnym obszarem badań jest wykluczenie społeczne: sposób, postawy, przyczyny, tożsamość osoby odrzucającej, obecność bądź brak wsparcia społecznego, skłonność do refleksji związanych z odrzuceniem,

9 Por. L. C y n a r z e w s k a - W 1 a ź 1 i k, Wspólnota. W naukach społecznych, w: EK, kol. 1001-1002; B. M i k o ł a j e w s k a, Zjawisko wspólnoty, New Haven 1999, s. 11-78. Autorka jako socjolog podejmuje opracowanie koncepcji socjologicznych dotyczących zjawiska wspólnoty. Mamy w tej publikacji prezentacje koncepcji C. Bell i H. Newby'ego, R. A. Nisbeta, Ch. H. Cooleya, E. Farisa, H. J. Gansa, L. Warrena, P. Saundersa, D. Rose, D. B. Clarka. Jednocześnie autorka podejmuje próbę opracowania wspólnotowości w odniesieniu do religii. Prezentuje w tej analizie ujęcia: J. D. Huntera, J. H. Fichtera, B. Wilsona, B. Lewenstein a także współczesnych zjawisk transformacji społecznej i miejsca wspólnotowości w ujęciu P. L. Bergera, B. Bergera, H. Kellnera, R. A. Nisbeta. 
sposób interpretowania, przyczyny odrzucenia, odpowiedzialność za zaistniałą sytuację, stopień doświadczenia odrzucenia. ${ }^{10}$

Na tym tle bardzo wyraźnie rysuje się szczególny rys wspólnotowości rozumianej na gruncie duchowości. Jest to przede wszystkim relacja w stosunku do osoby Boga, która ma charakter fundamentalny i tworzy zasadniczą wspólnotę, w stosunku do siebie oraz w stosunku do drugiego człowieka, mającego równorzędną osobowość i podmiotowość. ${ }^{11} \mathrm{Na}$ podkreślenie zasługuje zatem fenomen otwarcia człowieka na społeczność, co powoduje, że nie pozostaje on nomadą czy jednostką zamkniętą o charakterze samowystarczalnym. Mówimy wówczas o autotranscenedencji w kierunku „drugiego”. ${ }^{12} \mathrm{Nie}$ można tego przekraczania siebie ograniczyć jedynie do wymiaru praktycznego, ale człowiek dostrzega tę potrzebę w stosunku do próby odpowiedzi na zasadnicze, a jednocześnie fundamentalne pytanie, dotyczące doczesnej oraz ostatecznej jego egzystencji. Szczególny rys otwarcia na powszechność znajdujemy u św. Wincentego Pallottiego, który określał je w kontekście apostolstwa. Uważał, że skoro wszyscy są powołania do naśladowania Chrystusa, to także wszyscy otrzymali powołanie do apostolstwa, mającego charakter konstytutywny dla wspólnotowości. ${ }^{13}$

Podjęte zagadnienie wymaga także spojrzenia na relację jednostki do wspólnoty, ponieważ, jak zostało wykazane, między tymi dwoma rzeczywistościami istnieje nierozerwalna relacja. Zarówno jednostka nie jest samoistną nomadą, ale także wspólnota nie może

10 Por. M. P i ł a t - B o r c u c h, Pomiędzy tożsamościa osobowa a postawa społeczna, Zeszyty Naukowe Politechniki Śląskiej 65/2013, s. 317-327.

11 Por. KDK 23.

12 Por. S. K o w a l c z y k, Zarys filozofii człowieka, Sandomierz 1990, s. 204; M. Ta t a r, Od duszy artysty do artyzmu ducha. Collectanea Theologica 84(2014) nr 1, s. 121. Analiza fenomenu wspólnotowości i autotranscendencji w kierunku „drugiego" stała się podstawą całego dzieła zbudowanego przez św. Brata Alberta. Akcentując znaczenie ubóstwa, wskazuje na to, że wolność w każdej przestrzeni życia człowieka pozwala mu na tę autotranscendecję zarówno w kierunku Boga, jak również człowieka.

13 Por. J. S t a b i ń s k a, Wincenty Pallotti, Poznań 1982, s. 85. 
depersonalizować czy też deprecjonować odrębności jednostki. Jak twierdzi ks. prof. S. Kowalczyk, idąc za ujęciem K. Wojtyły w jego dziele Osoba i czyn, mamy do czynienia z różnorodnością modeli tej relacji. Za najbardziej reprezentatywne uznaje trzy, tj. kolektywizm, skrajny indywidualizm oraz personalizm. Uważa dwa pierwsze za wynaturzenia, które traktują relacje jednostki do społeczeństwa-wspólnoty w sposób ekstremalny. Pierwszy jest redukcjonistyczny i prowadzi do zatarcia indywidualności osoby, jednocześnie absolutyzując kolektywność. Jego klasycznym przedstawicielem jest marksizm. Drugi zaś, o charakterze liberalizującym, prowadzi z kolei do absolutyzacji jednostki. Jego geneza sięga do teorii atomizmu oraz nominalizmu. Jako przedstawicieli tego nurtu wymienia się Thomasa Hobbesa, Johna Locke'a, Jeana Jacques'a Rousseau. ${ }^{14}$ Skrajne podejście spotykamy u Jeana Paula Sartre’a, który uważa „bliźniego” za zaprzeczenie mojego ,ja”, kwestionującego moją podmiotowość. ${ }^{15}$

Sięgnięcie do rozwiązania personalistycznego pozwala nam w sposób realistyczny rozstrzygnąć problem. Ksiądz prof. W. Granat sugeruje, że zadaniem o wiele prostszym jest opis skonkretyzowanej społeczności, zaś trudniej jest wykazać, na czym polega jej istota. Z tego względu konieczne staje się odwołanie do nauk socjologicznych. Zakłada, że gdyby możliwa była precyzyjna odpowiedź na pytanie dotyczące istoty społeczności i jednostki w ich wzajemnej relacji, to socjologia okazałaby się dziedziną niepotrzebną. Z kolei już sama odpowiedź na pytanie o istotę społeczeństwa pozwoliłaby określić dokładnie, kim jest człowiek. ${ }^{16}$ Ostatecznie, analizując podjęte zagadnienie i odwołując się do E. Mouniera, nauki społecznej Kościoła oraz jego dokumentów, dochodzi do wniosku, że „osoba góruje nad społecznością przez swe ostateczne powołanie, ale osiąga swe zbawienie w społeczności Ludu Bożego. Mamy tu wzór harmonii

14 Por. tamże, s. 280.

15 Por. J. P. S a r t r e, L'êet le néant, Paris 1943, s. 26, 310-364.

16 Por. W. G r a n a t, Personalizm, Personalizm chrześcijański. Teologia osoby ludzkiej, Lublin 1982, s. 545. 
życia indywidualnego i społecznego". ${ }^{17} \mathrm{Z}$ kolei przywoływany już etyk, ks. prof. T. Ślipko, proponuje rozwiązanie pozornego, jego zdaniem, konfliktu między jednostkowością człowieka i jego uspołecznieniem. Zauważa, że człowiek jest bytem psychofizycznym a także indywiduum. Zauważamy również, że jest jednocześnie bytem zwróconym w relacji ku innym. Należy zatem podkreślić, że jako substancja ujednostkowiona jest bytem samoistnym. Relacja do innych wynika z zapotrzebowania ontycznego, czyli tkwiącego w naturze człowieka. Drugi człowiek do dobro odpowiadające naturze człowieka i dlatego przekracza on siebie w kierunku drugiej osoby. Konkludując, stwierdza, że indywidualność oraz uspołecznienie są dwoma różnymi kategoriami ontycznymi występującymi w naturze człowieka, co powoduje jedność, harmonię, przy jednoczesnym zróżnicowaniu. ${ }^{18}$

Waga relacji jednostki do wspólnoty odsłania także wzajemną zależność i oddziaływanie. Bez wątpienia we współczesnej rzeczywistości jesteśmy świadkami dość krańcowego odniesienia do jednostki a jednocześnie deprecjonowania wspólnotowości oraz procesu odwrotnego. Fakt ten ma zakorzenienie w całej szeroko rozumianej kulturze ludzkiej. W sposób jednoznaczny i bardzo klarowny podkreślił to Kościół w swoim nauczaniu: „Kim jest człowiek? Przedstawiał on i przedstawia wiele różnych a nawet sprzecznych opinii o sobie samym, w których często albo uważa siebie za normę absolutną, albo deprecjonuje się aż do rozpaczy, stając się przez to niezdecydowany i lękliwy”. ${ }^{19}$ Ten fakt „rozchwiania” został zauważony i poddany analizie przez Jana Pawła II w adhortacji apostolskiej Ecclesia in Europa. Papież widzi to zachwianie przede wszystkim w grzechu i fakcie odejścia człowieka od Boga, a tym samym utracie właściwego punktu odniesienia. Potraktowanie osoby Jezusa Chrystusa w kategoriach czasu przeszłego spowodowało utratę nadziei, a punktem odniesienia

\footnotetext{
17 Tamże, s. 549.

18 Por. T. Ś 1 i p k o, Zarys etyki szczegółowej, s. 15-116.

19 KDK 12.
} 
stał się dla siebie sam człowiek. ${ }^{20}$ To zachwiane spowodowane promocją antropologii bez Jezusa Chrystusa doprowadziło do powstania ideologii oraz praktycznych postaw i zachowań o charakterze skrajnie egocentrycznym, indywidualistycznym oraz subiektywistycznym. ${ }^{21}$ Idąc za myślą papieża Benedykta XVI, należy stwierdzić, że mamy do czynienia rzeczywiście z dyktaturą relatywizmu, podważającego obiektywną zasadność prawdy. ${ }^{22}$ Atak kierunków sekularystycznych doprowadził do zachwiania podstawowej wspólnoty, jaką jest rodzina. ${ }^{23} \mathrm{~W}$ ten sposób w całym procesie formacyjno-wychowawczym opartym na wierze, która nierozerwalnie związana jest z modlitwą, mamy do czynienia z poważnym zaburzeniem rozumienia jej wspólnotowości.

\section{Modlitwa wspólnotowa oraz wspólna}

Aby dokonać właściwej analizy tego rodzaju modlitwy, konieczne jest nakreślenie natury modlitwy jako takiej, co okazuje się zadaniem niełatwym ze względu na różnorodność koncepcji, ujęć, a także podkreślania przez teologów oraz mistrzów życia duchowego

20 Por. J a n P aw e ł II, Adhortacja apostolska Ecclesia in Europa (dalej: EE), Rzym 28 VI 2003. Papież, nawiązując do Drugiego Zgromadzenia Specjalnego Biskupów, które zostało poświęcone Europie, stwierdza: „Wśród wielu aspektów, szeroko zarysowanych również przy okazji Synodu, chciałbym przypomnieć utratę pamięci i dziedzictwa chrześcijańskiego, któremu towarzyszy swego rodzaju praktyczny agnostycyzm i obojętność religijna, wywołująca u wielu Europejczyków wrażenie, że żyją bez duchowego zaplecza, niczym spadkobiercy, którzy roztrwonili dziedzictwo pozostawione im przez historię. Nie dziwią zatem zbytnio próby nadania Europie oblicza wykluczającego dziedzictwo religijne, a w szczególności głęboką duszę chrześcijańską, przez stanowienie praw dla tworzących ją ludów, w oderwaniu od ich życiodajnego źródła, jakim jest chrześcijaństwo”.

21 Por. tamże, nr 8-9.

22 Por. J. Wa r z e s z a k, „Dyktatura” relatywizmu w ujęciu Benedykta XVI, Warszawskie Studia Teologiczne XXIV/1/2011, s. 291-322; R. d e M a t t e i, Dyktatura relatywizmu, tłum. P. T o b oła - P e r t k i e w i c z, E. Tu r l i ń s k a, Warszawa 2009, s. 23-48.

23 Por. EE, nr 8. 
szczególnych dla nich elementów, które uznają za zasadnicze oraz konstytutywne. Ksiądz A. Słomkowski, zajmując się tym zagadnieniem, dokonał zestawienia najważniejszych określeń, które mają wpływ na kształtowanie się teologii modlitwy. Dla św. Grzegorza z Nyssy ,jest obcowaniem, czyli rozmową z Bogiem”, według św. Augustyna „modlitwa jest myślą o Bogu z sercem pobożnym i pokornym”, św. Jan Klimak twierdzi, że „modlitwa jest obcowaniem i zjednoczeniem człowieka z Bogiem", natomiast św. Jan Damasceński określa ją słowami: ,Jest wzniesieniem duszy do Boga” i „,prośbą zanoszoną do Niego o rzeczy właściwe". ${ }^{24}$ Ksiądz Z. Nabzdyk twierdzi, że pośród istotnych określeń należy zaznaczyć definicję Ewagriusza z Pontu, który określa ją jako wzniesienie ducha ku Bogu. Jak zaznacza autor opracowania, tu znajduje się początek definicji, którą przyjął Zachód, a która jest przypisywana św. Janowi Damasceńskiemu. Ksiądz prof. S. Urbański w swoim opracowaniu bardzo wyraźnie wskazuje na św. Jana Damasceńskiego, przytaczając konkretnie jego słowa, że modlitwa to „wzniesienie duszy do Boga”. Opiera się na licznych opracowaniach, a przede wszystkim na dziele samego św. Jana Damasceńskiego De fide ortodoxa 3, 24; PG 94, 1089. ${ }^{25} \mathrm{Z}$ kolei św. Tomasz z Akwinu stwierdza, że w modlitwie mamy do czynienia ze wzniesieniem się człowieka ku Bogu przy aktywnej funkcji umysłu ludzkiego. ${ }^{26}$ Do przytoczonych prób określenia modlitwy należy dodać ujęcie św. Teresy z Avila, która właściwie całość schematu dynamiki rozwoju życia duchowego oparła właśnie na jej rozwoju. W jej pismach znajdujemy następujące określenie: „Modlitwa jest

24 Por. A. S ło m k o w s k i, Teologia życia duchowego, Ząbki 2000, s. 199.

25 Por. S. U r b a ń s k i, Teologia modlitwy, Warszawa 1999, s. 26.

26 Por. Ś w. To mas z z A k w i n u, STh II-II, 83, 17. Jest to bardzo znamienna dla teologii duchowości definicja, która w ujęciu św. Tomasz brzmi następująco: „Oratio rationis est actus, applicantis desiderium voluntatis ad eum, qui nin est potestate nostra sed supra nos, sciliced Deum” (,Modlitwa jest aktem rozumu kierującego pragnienie woli do tego, który nie podlegając naszej władzy jest ponad nami, to jest Boga"). 
przyjaznym obcowaniem i wiele razy powtarzaną poufną rozmową z Tym, o którym wiemy, że nas kocha". ${ }^{27}$

Odwołując się do współczesnych teologów, warto podkreślić w tym względzie ujęcie K. Rahnera, który akcentuje takie elementy jak naturalne i nadprzyrodzone odniesienie człowieka do Boga, spotkanie rzeczywistości ludzkiej z tajemnicą Boga, odpowiedź człowieka w postawie pokory i postawa dyspozycyjności wobec Boga, wartościujące objęcie wszystkich świadomych aktów religijnych. Z kolei podkreślając, że jest to dar Boga i jednocześnie działanie człowieka, J. Subrak akcentuje dialogiczny charakter modlitwy. ${ }^{28} \mathrm{Dla}$ R. Guardiniego określenie modlitwy zacieśnia się do pojęcia relacji „ja” do „Ty”. Jednakże należy podkreślić, że konieczne jest określenie relacji, ze względu na ich różnorodność i panujące w związku z tym rozbieżności. ${ }^{29}$

27 S a n t a Teresa, Libro de la Vida, w: T. Ál varez (red.), Obras completas, Burgos 2104, c. 8, 5: „Que no es otra cosa oración mental, a mi parecer, sino tratar de amistad, estando muchas veces tratando a solas con quien sabemos nos ama".

28 Por. Z. N a b z d y k, Modlitwa-źródło i wyraz duchowości, w: W. Sło m k a, M. Ch m i e l e w s k i, J. M i s i u r e k, A.J. N ow a k (red.), Teologia duchowości katolickiej, Lublin 1993, s. 125; W.R. M a c k o, Rola i znaczenie modlitwy w życiu świeckich w świetle nauczania kard. Stefana Wyszyńskiego, Collectanea Theologica 76(2006) nr 1, s. 94. Autor stwierdza: „Człowiek, dzięki modlitwie, zdolny jest właściwie ocenić swoje działanie i odnieść je do Boga - dawcy wszelkich dóbr".

29 Por. R. G u a r d i n i, Vorschule des Betens, Leipzig 1960, s. 209; K. G ó ź d ź, Teologia człowieka, Lublin 2006, s. 205. Autor, komentując, stwierdza, że relacja do Boga, który z człowiekiem wchodzi w osobowy kontakt prowadzi do powstania wspólnoty wiary. Religijność jest przejawem życia społecznego realizującego się nie tylko na płaszczyźnie kontaktu międzyludzkiego, ale w zakresie doświadczenia wiary jest także uspołecznieniem ukierunkowanym na dialogiczny kontakt z Bogiem. Właśnie tak realizuje się przekroczenie materialności człowieka w kierunku transcendencji. Jest to ,ja” poszukujące absolutnego „Ty” wynikające z potrzeby ontologicznej. M. J a g o d z i ń s k i, Communio dzięki komunikacji. Teologiczny wymiar teorii komunikatywnego działania w eklezjologii Medarda Kehla SJ, Radom 2002, s. 18-23. Autor podkreśla, że rozwój życia religijnego charakteryzującego się dynamizmem wiary wprowadza człowieka w komunikatywny sposób bytowania osoby człowieka z osobą Boga. W taki sposób konstytuuje się wspólnotowy wymiar Kościoła, który w rozumieniu M. Kehla jest „sakramentem Komunii Boga”. 
Konkludując tę prezentację, należy odwołać się do wykładni nauki Kościoła. Katechizm Kościoła Katolickiego definiuje modlitwę słowami: „Modlitwa jest wzniesieniem duszy do Boga lub prośbą skierowaną do Niego o stosowne dobra" ${ }^{30}$ zaznaczając jednocześnie, że jest ona darem Boga, przymierzem oraz komunią. ${ }^{31} \mathrm{Z}$ punktu widzenia podjętego zagadnienia szczególnie ten ostatni aspekt jest niezwykle istotny i znajdujemy następujące dopowiedzenie: „Modlitwa jest o tyle chrześcijańska, o ile jest komunią z Chrystusem i rozszerza się w Kościele, który jest Jego Ciałem. Ma ona wymiary miłości Chrystusa". ${ }^{32}$ Oznacza to, że jest ona dążeniem do jedności z Jezusem Chrystusem, budując jednocześnie z Nim nadprzyrodzoną i widzialną wspólnotę.

Analiza modlitwy odsłania różnorodność jej rodzajów. Podziały te wynikają z zastosowanych kryteriów, tj. jej treści (prośba, uwielbienie, dziękczynienie i przebłaganie), sposobu formułowania, wyrażania modlitwy czy też praktyki (ustna, myślna), a także formy praktyki (publiczna bądź liturgiczna, wspólnotowa, indywidualna). W podjętej analizie szczególnie interesuje nas modlitwa wspólnotowa. Odwołując się do podstaw biblijnych, zarówno Starego jak również Nowego Testamentu, ${ }^{33}$ możemy znaleźć liczne przykłady. Lektura Ewangelii bardzo wyraźnie wskazuje na postawę Jezusa Chrystusa, który się modlił (por. Łk 6, 12; 9, 18-20; 22, 32. 42; Mk 1, 35; J 11, 41-42; 17, 6-26) ale także uczył apostołów modlitwy (por. Łk 11, 1-4). ${ }^{34}$ Wszystkie te momenty znajdują swój punkt kulminacyjny w słowach Jezusa Chrystusa: ,...zaprawdę, powiadam wam: Jeśli dwaj z was na ziemi zgodnie o coś prosić będą, to wszystkiego użyczy im mój Ojciec, który

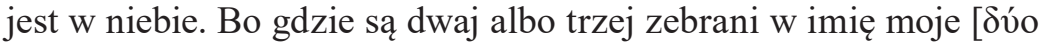

KKK 2559.

31 Por tamże, 2560-2565; A. Z u b e r b i e r, Korzenie i natura modlitwy chrześcijan według ,,Katechizmu Kościoła Katolickiego”, Collectanea Theologica 65 (1995) nr 2, s. 37-38.

32 KKK 2565.

33 Por. Z. N a b z d y k, Modlitwa - źródto i wyraz duchowości, s. 126-127;

D. W i d e r, Zawsze się módlcie, Kraków 1999, s. 13-16.

34 Por. tamże, s. 39-40. 
ì

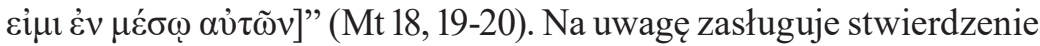

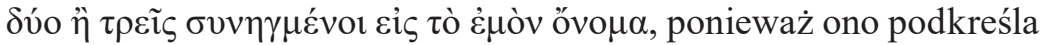
komunio-twórczy charakter modlitwy, a jednocześnie precyzuje zasadniczy jej motyw. Równie ważne jest dalsze stwierdzenie $\dot{\varepsilon} v \mu \varepsilon ́ \sigma \omega$ $\alpha u ̉ \tau \tilde{v} v$, które wskazuje na charakter obecności Chrystusa. Oznacza to, że modlitwa jest wspólnotowa ze swej natury, ponieważ jedność z Jezusem Chrystusem rodzi zasadniczy charakter wspólnoty z Nim. Z tego względu możemy mówić o modlitwie przeżywanej indywidualnie przez człowieka, ale nigdy nie jest ona prywatna, redukowalna jedynie do poziomu człowieka ${ }^{35} \mathrm{~W}$ tym kontekście zauważamy wage i znaczenie eklezjalnego wymiaru modlitwy, ponieważ Kościół stanowi communio oparte na obecności Jezusa Chrystusa jako jego Głowy (por. Kol 1, 18; Ef 4,11--16). Idąc za św. Tomaszem z Akwinu, stwierdzamy, że zarówno Głowa stanowi jedność z członkami, jak również ta więź dotyczy tych, którzy do Chrystusa oraz Kościoła przynależą. ${ }^{36}$ To również sprawia, że każda modlitwa chrześcijanina ma charakter wspólnotowy i dokonuje się w całej wspólnocie Kościoła, tzn. w obecności świętych i błogosławionych, przebywających w czyśćcu oraz żyjących. Aspekt ten ma bardzo bogate udokumentowanie w modlitwie i duchowości, choćby św. Wincentego Pallottiego. ${ }^{37}$

35 Por. J. G o g o l a, Teologia komunii z Bogiem, Kraków 2001, s. 290-291.

36 Por. Ś w. Tom a s z z A k w in u, STh. III, 48, 2, ad 1; W.R. M a c k o, Rola $i$ znaczenie modlitwy w życiu świeckich, s. 96. Autor określa tę relacje mianem zależności słowami: „Modlitwa, jako wyraz relacji między stworzeniem a Stwórcą, jest uznaniem pełni zależności bytowej i podporządkowaniem w sferze dynamicznej. Pamiętając o tym, człowiek wykonuje zadania nie po to, aby urzeczywistnić zamierzony plan, zdobyć środki do życia, czy uzyskać czyjeś względy, ale dlatego, że ma to wartość przed Bogiem”.

37 Por. Ś w. W i n c e n t y P a 11 o t t i, Wybór pism, t. IV, tłum. F. B o g d a n, Ząbki 2001, s. 44. Warto jako przykład skazać następujący zwrot modlitewny „Proszę cię, Niepokalana Matko Boża Królowo Apostołów, abyś raczyła połączyć się z najniegodniejszym synem, z wszystkimi Aniołami i Archaniołami oraz ze wszystkimi Świętymi nieba dla podziękowania Przeniajśw. Trójcy za użyczony mi dar Wiary świętej”. 
Sięgając do podejmowanych prób zdefiniowania modlitwy wspólnotowej, co wydaje się bardziej właściwym określeniem niż używane przez ks. prof. M. Chmielewskiego słowo „zbiorowa”, ${ }^{38}$ należy stwierdzić, że autorzy odwołują się do podwójnej argumentacji, tzn. teologicznej, która została zasygnalizowana wyżej, jak również socjalno-antropologicznej, ze względu na to, że człowiek ze swej natury jest animal sociale. ${ }^{39}$ Niestety, w wielu przypadkach dochodzi do dość poważnej pomyłki i modlitwę wspólnotową identyfikuje się z modlitwą wspólną. Jak już zostało podkreślone, każda modlitwa ma charakter wspólnotowy, zaś nie każda jest sprawowana wspólnie. Modlitwa wspólnotowa dotyka przede wszystkim zasadniczych podstaw i motywów. Na temat modlitwy wspólnej zostanie podjęta próba prezentacji jej charakteru oraz znaczenia. Ojciec prof. J. Gogola, dokonując kategoryzacji modlitw, uznaje modlitwę wspólnotową za wymiar modlitwy liturgicznej. ${ }^{40}$ Nie do końca można się z takim zakwalifikowaniem zgodzić. Modlitwa liturgiczna może być sprawowana indywidualnie a także wspólnie, tzn. w grupie modlących się, ale zawsze ma charakter wspólnotowy, zgodnie z tym, co zostało powiedziane. Jednakże modlitwa wspólnotowa nie zawsze musi być liturgiczna. Kościół zna i praktykuje wiele form modlitwy pozaliturgicznej sprawowanej we wspólnocie bądź też indywidualnie. Wagę zarówno samej modlitwy wspólnotowej, jak również wyraźne wyszczególnienie tej kategorii, znajdujemy w ujęciu ks. prof. J. Misiurka, który zaznacza, że wyjątkowego znaczenia nabiera modlitwa Liturgią Godzin a także Eucharystia. ${ }^{41}$ Niestety, analiza lubelskiego teologa została zawężona do dokumentów dotyczących wspólnotowego charakteru modlitwy liturgicznej i niekiedy myli on ją z modlitwą wspólną. Poza tym pewien niedosyt wzbudza ograniczenie analizy tego zagadnienia do wymiaru życia konsekrowanego oraz

38 Por. M. C h m i e le w s k i, Vademecum duchowości chrześcijańskiej, Lublin 2004, s. 176.

39 Por. Z. N a b z d y k, Modlitwa-źródło i wyraz duchowości, s. 131-132.

40 Por. J. G o g o l a, Teologia komunii z Bogiem, s. 304.

${ }^{41}$ Por. J. M i s i u r e k, Modlitwa. Medytacja. Mistyka, Lublin 2011, s. 159. 
kapłańskiego. ${ }^{42}$ Wspólnotowy charakter modlitwy dotyczy każdej formy życia i podkreśla zasadniczy element życia uświęcającego w odniesieniu do powszechnego powołania do świętości, który tak mocno postuluje II Sobór Watykański. ${ }^{43}$ Właśnie wspólnotowość, która ma charakter nadprzyrodzony, chrystocentryczny, pneumatologiczny i głęboko eklezjalny, jest zwornikiem całego modlącego się Kościoła Wspólnoty. Uniwersalizm powołania do świętości stał się motywem do spojrzenia na wspólnotowość przez św. Wincentego Pallottiego. Stwierdza on, że słowa Psalmu 117/116 klarownie podkreślają, że modlitwa jest konstytuowana właśnie przez świadomość powszechności. ${ }^{44}$

Modlitwa wspólna to bardzo istotna kategoria, która może być pewną składową modlitwy wspólnotowej. Ten rodzaj modlitwy dotyczy i opisuje wspólnotę osób modlących się, która ma skonkretyzowany charakter oraz urzeczywistnia się we wspólnocie całego Kościoła. To wyszczególnienie jest konieczne ze względu na zasadniczą różnicę. Warto podkreślić zapewnienie, jakie Chrystus pozostawił co do skuteczności takiej modlitwy: „Dalej, zaprawdę, powiadam wam: Jeśli dwaj z was na ziemi zgodnie o coś prosić będą, to wszystkiego użyczy im mój Ojciec, który jest w niebie" (Mt 18, 19). Praktyka Kościoła pierwszych wieków bardzo wyraźnie podkreślała ten sposób modlitwy, który ma wymiar wspólnototwórczy oraz eklezjotwórczy. Święty Tomasz z Akwinu przyznawał tej modlitwie szczególny charakter, stwierdzając, że jej skuteczność dotyczy nie tylko żyjących ale także grzeszników, którzy w takim stanie zakończyli życie doczesne. ${ }^{45}$ Idąc za teologią Wschodu, można powiedzieć, że modlitwa ma charakter i wymiar kosmiczny. Jednakże Jan Klimak zgodnie $\mathrm{z}$ duchem Wschodu i na podstawie doświadczenia pustyni stwierdza: „Jeśli śpiewacie w kościele z wielką liczbą osób, ciężko wam będzie uczynić waszą modlitwę duchową i odseparowaną od

\footnotetext{
42 Por. tamże, s. 167-171.

43 Por. KK 39.

44 Por. J. S t a b i ńs k a, Wincenty Pallotti, s. 85.

45 Por. Św. Tomas z z A kw in u, STh II-II, q 83, a. 7.
} 
jakiegokolwiek obrazu i wrażeń zmysłowych". ${ }^{46}$ Podkreśla także realne niebezpieczeństwo próżności, roztargnień i rozproszeń a także nieporządku we wspólnym sprawowaniu modlitwy. ${ }^{47} \mathrm{Z}$ kolei Jan Chryzostom zaznacza: „Można modlić się we własnym domu, ale nie można równie dobrze modlić się, jak w kościele (...) Tutaj królują jednomyślność i zgoda, wieź miłości i modlitwy kapłanów. Temu służy obecność kapłanów: modlitwy wspólnoty są słabsze i przyłączają się do modlitw kapłanów, które są silniejsze, i wszystkie razem wznoszą się do nieba". ${ }^{48}$

Sięgając do Instrukcji o życiu kontemplacyjnym i o klauzurze mniszek Kongregacji Instytutów Życia Konsekrowanego i Stowarzyszeń Życia Apostolskiego Venite seorsum, znajdujemy niezwykle istotne stwierdzenie: „Ich modlitwa, zwłaszcza udział w Eucharystycznej Ofierze Chrystusa i odprawianie świętego oficjum jest pełnieniem najwspanialszego zadania wspólnoty modlących się, jaką jest Kościół, a mianowicie wielbieniem Boga". ${ }^{49}$ Podobnie określa Liturgię Godzin Wprowadzenie do niej, stwierdzając, że ta codzienna modlitwa Kościoła ma charakter wspólnototwórczy. W ten sposób nie tylko sprawowany jest kult w określonej wspólnocie wierzących, ale jednocześnie jest to niezwykle istotny środek formacji. Domaga się on rezygnacji ze swojego indywidualizmu, ale także uległości wobec modlitewnego porządku, który wynika z harmonogramu dnia zakonnego, kapłańskiego czy też życia małżeńsko-rodzinnego. Bardzo jednoznaczne stwierdzenie odnajdujemy w kolejnej instrukcji Kongregacji życia Konsekrowanego i Stowarzyszeń Życia Apostolskiego Congregavit nos in unum Christi amor: „Wspólna modlitwa, która zawsze była uważana za podstawę wszelkiego życia wspólnotowego, rodzi się z kontemplacji wielkiej i wzniosłej tajemnicy Boga, z podziwu dla

46 Jan K 1 i ma k, Scala Paradisi, 18, 7 PG 8, 937 d.

47 Por. tamże, 4, 91, $713 \mathrm{~d}$.

48 Jan Chryzos to m, De incomprehensibili dei natura 3, PG 48, 726.

49 Kongregacja Instytutów Życia Konsekrowanego i Stowarzyszeń Ży cia A postolsk i e go, Instrukcja: O życiu kontemplacyjnym i o klauzurze mniszek ,Venite seorsum”, Rzym 15 VIII 1969, nr 3. 
Jego obecności, ujawniającej się w najbardziej doniosłych chwilach w życiu naszych rodzin zakonnych, jak również w skromnej i codziennej rzeczywistości naszych wspólnot". ${ }^{50}$ Zauważamy jednocześnie, że modlitwa wspólna nie stoi w sprzeczności z pozostałymi formami modlitwy, ale, wręcz przeciwnie, ma z nimi wewnętrzną i zewnętrzną spójność. ${ }^{51}$ Podobnie stwierdza Jan Paweł II, odwołując się do praktyki Kościoła od jego początków i akcentując znaczenie tej modlitwy do autentycznego rozwoju wspólnoty życia. ${ }^{52} \mathrm{~W}$ niej upatruje podstawę prawdziwie komunijnego życia. ${ }^{53}$

Idąc za myślą ks. prof. S. Urbańskiego, należy podkreślić, że podstawą a zarazem najgłębszym motywem komunijnego zjednoczenia w modlitwie jest miłość. Przede wszystkim ukierunkowana jest ona na Boga, ku któremu każdy z biorących udział w modlitwie się zwraca. Następnie niezbędna jest ona w relacjach międzyludzkich. $\mathrm{W}$ ten sposób rzeczywiście modlitwa, wynikająca $\mathrm{z}$ autentycznej miłości i wyrażająca ją, może przynosić owoce dla wspólnoty modlących się. Warszawski teolog, uzasadniając swoją analizę, odwołuje się do twierdzenia o. J. Woronieckiego, że jest to ,związek wysiłków

50 T a ż, Instrukcja: Życie braterskie we wspólnocie „Congregavit nos in unum Christi amor”, Rzym 4 II 1994, nr 12

51 Por. tamże, nr 15. „Modlitwa wspólnotowa osiąga pełną skuteczność, kiedy jest wewnętrznie zespolona z modlitwą osobistą. Modlitwa wspólna i modlitwa osobista są bowiem ściśle z sobą związane i wzajemnie się uzupełniają. Wszędzie, ale zwłaszcza w pewnych regionach i kulturach, trzeba kłaść szczególny nacisk na wymiar wewnętrzny, na synowską więź z Ojcem, na osobisty i oblubieńczy dialog z Chrystusem, na osobiste pogłębienie tego, co stanowiło treść modlitwy wspólnotowej, na ciszę wewnętrzną i zewnętrzną która stwarza potrzebną przestrzeń, aby Słowo i Duch mogły odrodzić najtajniejsze głębie ludzkiego serca”.

52 Por. Ja n Paweł II, Adhortacja apostolska Vita consecrata, Rzym 25 III 1996, nr 45: „Zachęcam zatem osoby konsekrowane, by troskliwie rozwijały życie braterskie, idąc za przykładem pierwszych chrześcijan Jerozolimy, którzy trwali w słuchaniu nauki Apostołów, we wspólnej modlitwie, w sprawowaniu Eucharystii, we wspólnocie dóbr natury i darów łaski (por. Dz 2, 42-47)”.

53 Por. tamże, nr 51: „Wspólnoty te są miejscami nadziei i odkrywania ducha Błogosławieństw - miejscami, w których miłość, czerpiąca moc z modlitwy, źródła komunii, ma stawać się zasadą życia i zdrojem radości”. 
ludzkich w akcie modlitewnym". ${ }^{54}$ Punktem centralnym jest spotkanie i doświadczenie Jezusa Chrystusa. On staje się zarówno źródłem, jak również celem communio międzyludzkiego, w którym ogromną rolę pełni wzajemne wstawiennictwo.

Należy w tym kontekście podkreślić jeszcze jeden aspekt, którym jest świadectwo zewnętrzne wspólnoty modlącej się. Wynika ono z modlitwy a jednocześnie prowadzi do jej pogłębienia. Z tego względu, idąc za myślą ks. prof. S. Urbańskiego, należy uznać wyższość tego rodzaju modlitwy nad indywidualną czy też osobistą. ${ }^{55}$

\section{Praktyczne urzeczywistnianie się modlitwy wspólnotowej}

Modlitwa wspólnotowa oraz wspólna odsłania swój charakter w bardzo konkretnych formach liturgicznych oraz paraliturgicznych (pozaliturgicznych). ${ }^{56} \mathrm{~W}$ praktyce Kościoła oraz wierzących stanowi ona szczególny dar a jednocześnie wyzwanie. Jak zostało stwierdzone, św. Wincenty Pallotti podkreślał ją jako, tzw. modlitwę apostolską ${ }^{57}$ Kościół na pierwszym miejscu umieszcza modlitwę liturgiczną, która jest wyrazem modlitwy wszystkich wierzących. Idąc za jego nauką, stwierdzamy, że „Kościół, który nieustannie wielbi Pana i wstawia się za zbawienie całego świata nie tylko przez celebrowanie Eucharystii, lecz także innymi sposobami, zwłaszcza przez modlitwę godzin". ${ }^{58} \mathrm{Na}$ ten temat mamy bardzo wiele opracowań, zarówno na gruncie ściśle teologicznym, jak również duchowości praktycznej. Koncentruje się ona przede wszystkim na celebracji sakramentów oraz Officium Divinum. ${ }^{59} \mathrm{~W}$ definicjach określających

54 Por. S. U r b a ń s k i, Teologia modlitwy, s. 267; W.R. M a c k o, Rola i znaczenie modlitwy w życiu świeckich, s. 97.

55 Por. tamże.

56 Por. S. W it e k, Teologia życia duchowego, Lublin 1986, s. 288; W.R. M a c k o, Rola i znaczenie modlitwy w życiu świeckich, s. 101.

${ }^{57}$ Por. Ś w. W i n c e n t y P a llot ti, Wybór pism, s. 16-18; J. S t a b i ń s k a, Wincenty Pallotti, s. 114.

$58 \mathrm{KL} 83$.

59 Por. J. G o g o l a, Teologia komunii, s. 304. 
ten rodzaj modlitwy teologowie podkreślają przede wszystkim to, że jest ona kultem publicznym sprawowanym przez Kościół oraz ma charakter urzędowo określony. Oznacza to, że sposób sprawowania kultu ma ściśle określone ramy prawno-liturgiczne, niepodlegające zmianom. Oczywiście, pod względem treści zawierają one te zasadnicze formy, jak dziękczynienie, prośba, błaganie, uwielbienie oraz przebłaganie. Skoro ta modlitwa jest modlitwą całego Kościoła, tzn. że jej owoce, a także konsekwencje jej sprawowania bądź zaniechania, dotykają całego Mistycznego Ciała Chrystusa. Z tego względu jej skuteczność nie ogranicza się do pojedynczych wierzących czy też partykularnych wspólnot, ale ma charakter ex opere operantis Ecclesiae. ${ }^{60}$

Jak już zostało zasygnalizowane, centrum modlitwy liturgicznej modlitwy Kościoła stanowi celebracja sakramentów św., pośród których kulminacją jest sprawowanie Eucharystii. ${ }^{61}$ Należy zatem stwierdzić że modlitwa sakramentalna ma charakter zasadniczy w stosunku wszystkich innych jej rodzajów oraz kategorii. Takie ich miejsce i rola wynika z natury samych sakramentów. Bazując na stwierdzeniu św. Augustyna, który określa sakramenty jako „signum rei sacra, in quantum est sacrificans hominem", ${ }^{62}$ stwierdzamy, że sprawiają one w człowieku to, co oznaczają, rozwijając w sposób sukcesywny rzeczywistość nadprzyrodzoną. Jak twierdzi św. Tomasz z Akwinu, wraz z łaską uświęcającą człowiek otrzymuje jeszcze łaskę sakramentalną, która związana jest ze specyfiką każdego z sakramentów. ${ }^{63} \mathrm{~W}$ kontekście omawianego zagadnienia należy jednak podkreślić odniesienie do Chrystusa, jako Prasakramentu, oraz Kościoła, który jest ,jakby sakramentem, czyli znakiem i narzędziem zewnętrznego zjednoczenia z Bogiem i jedności całego

${ }^{60}$ Por. S. U r b a ń s k i, Teologia modlitwy, s. 245-254; S. W i te k, Teologia życia duchowego, s. 288.

${ }_{61}$ Por. A. Z u b e r b i e r, Korzenie i natura modlitwy chrześcijan, s. 43-45.

62 Św. Tomasz z A kw inu, STh III, q. 60, a. 2.

63 Por. tamże, q. 62, a. 2. 
rodzaju ludzkiego". ${ }^{64}$ Ostateczne sformułowanie soborowe podkreśla charakter uświęcająco-komuniotwórczy sakramentów. Jak zaznacza nauka Kościoła ,jest nam udzielane życie Boże” oraz „urzeczywistniają łaski". ${ }^{65}$ W ten sposób wyraźnie zauważamy, że sakramenty, posiadając wymiar personalistyczny, są nie tylko znakami o charakterze zewnętrzno-liturgicznym. Mają one strukturę i charakter komunijno-dialogiczny i w nich dokonuje się jednoczenie człowieka z Bogiem. Zatem, używając współczesnego języka teologicznego, który swoje źródło ma w nauce soborowej, ${ }^{66}$ możemy powiedzieć, że każdy sakrament z osobna i wszystkie razem są przestrzenią communio człowieka z Bogiem. Pośród nich centrum stanowi Eucharystia. ${ }^{67}$ Można powiedzieć, że jest to szczyt interpersonalnego spotkania chrześcijanina z Bogiem (por. 1Kor 10, 16n.), który nosi znamiona najważniejszego zjednoczenia w doświadczeniu doczesnym a jednocześnie ma skutki eschatologiczne, czyli jego owoce sięgają pełni świętości (por. Łk 22, 14-23). Bardzo istotne wyjaśnienie w tym względzie odnajdujemy w słowach Jana Pawła II: „Sam Jezus zapewnia, że owo zjednoczenie, związane przez Niego przez analogię, ze zjednoczeniem, jakie ma miejsce w życiu trynitarnym, naprawdę się realizuje". ${ }^{68}$ Jako wzór wskazuje na Maryję oraz analogię między Jej fiat, a ludzkim amen ${ }^{69}$ Ten akcent wspólnotowy, a jednocześnie

64 KKK 775; A. S ło m k o w s k i, Teologia życia duchowego, s. 69.

65 KKK 1131.

66 Por. KK 7.

${ }^{67}$ Por. DP 5. Jest to niezwykle istotne stwierdzenie z punktu widzenia relacji między sakramentami: „Inne zaś sakramenty, tak jak wszystkie kościelne posługi i dzieła apostolstwa, wiążą się ze świętą Eucharystią i do niej zmierzają. W Najświętszej bowiem Eucharystii zawiera się całe duchowe dobro Kościoła...”.

${ }^{68} \mathrm{~J}$ a n Pawe 1 II, Encyklika Ecclesia de Eucharistia, Rzym 17 IV 2003, nr 16.

${ }^{69}$ Por. tamże, nr 55. Ta analogia papieska jest tak istotna i jednocześnie w tak głęboki sposób odzwierciedla relację, że warto przytoczyć cały fragment: „Eucharystia odsyłając do męki i zmartwychwstania, wyraża jednocześnie ciągłość z tajemnicą Wcielenia. W zwiastowaniu Maryja poczęła Syna Bożego również w fizycznej prawdzie ciała i krwi, antycypując w sobie to, co w jakiejś mierze realizuje się sakramentalnie w każdym wierzącym, który przyjmuje pod postacią chleba i wina 
eucharystyczny oraz maryjny, znajdujemy w pismach św. Wincentego Pallottiego. ${ }^{70}$

Uwzględniając modlitewny charakter sakramentów, nie można ich traktować jedynie w kategoriach liturgiczno-obrzędowych, ale przede wszystkim komuniotwórczo-uświęcających. Właśnie modlitewność nadaje im zasadnicze znaczenie, sprawiając, że stają się one źródłem i środkiem dynamiki rozwoju życia duchowego chrześcijanina. Każdy sakrament w swojej specyfice łaski, którą obdarza chrześcijanina, jest aktem zwrócenia się ku Bogu a jednocześnie Jego działaniem w życiu człowieka. To właśnie w ten sposób urzeczywistnia się modlitewny dialog uświęcający, który jest najgłębszą naturą modlitwy. ${ }^{71}$ Jak twierdzi ks. D. Wider, idąc za kard. A. Bellestrero, „modlitwa sakramentów swoim konkretem przede wszystkim napełniając łaską i karmiąc Słowem Bożym, daje moc i solidny pokarm. W ten sposób broni przed sentymentalizmem". ${ }^{72}$ Jednocześnie autor zaznacza organiczny związek między modlitwą osobistą i sakramentalną stwierdzając: ,...pozwala przez rozważania i milczącą kontemplację dać głębię modlitwie sakramentów".73

Ciało i Krew Pańską"; J. R a t z i n g e r, Duch liturgii, tłum. E. P i e c i u 1, Poznań 2002, s. 28. Kardynał Ratzinger, próbując uchwycić rzeczywistość przeistoczenia i doświadczenia przez świat tej sakralności, odwołuje się do Teilharda de Chardin i jego interpretacji Listu do Efezjan oraz Listu do Kolosan. Z tej perspektywy, jak twierdzi Ratzinger: „Przeistoczona Hostia jest w jego rozumieniu antycypacją przeistoczenia materii i jej przebóstwienia w chrystologicznej «pełni». Eucharystia wyznacza według niego kierunek kosmicznego ruchu: antycypuje ona cel ruchu i zmierzając do celu, ruch ów wywołuje".

70 Ś w. W i n c e n t y Pall ot ti, Wybór pism, s. 27-28: „Wprzód jednak wszyscy razem błagajmy wspaniałą Matkę Bożą i Matkę naszą, by sama raczyła przywieść nas do nawiedzenie Boskiego swego Syna w Najśw. Sakramencie Ołtarza. (...) Gdy więc wszyscy z Tobą zjednoczeni, wszyscy z Tobą utożsamieni - uczynieni z Tobą czymś jednym jesteśmy, przyjdź Ty sam, nawiedź samego siebie w Najśw. Sakramencie Ołtarza”. A. Z u b e r b i e r, Korzenie i natura modlitwy chrześcijan, s. 45-46.

71 Por. KKK 2558; D. W i d e r, Zawsze się módlcie, s. 127-128.

72 Tamże, s. 128.

73 Tamże. 
Liturgia Godzin, jak to już zostało zasygnalizowane, należy do liturgicznej formy modlitwy Kościoła, ale zarazem ma charakter głęboko wspólnotowy i niejednokrotnie wspólny, tzn. celebrowana jest w grupie modlących się. Katechizm Kościoła Katolickiego wskazuje na jej jedność organiczną z Eucharystią stwierdzając: „Misterium Chrystusa, Jego Wcielenie i Pascha, które celebrujemy w Eucharystii zwłaszcza podczas niedzielnego zgromadzenia, przenika i przemienia czas każdego dnia przez celebrację Liturgii Godzin, Officium divinum". ${ }^{74}$ Ważność i wagę tej modlitwy odzwierciedlają słowa nauczania Kościoła: ,....jest to głos Oblubienicy przemawiającej do Oblubieńca. Co więcej. Jest to ponadto modlitwa, w której Chrystus wraz ze swoim Ciałem zwraca się do Ojca". ${ }^{75}$ Chrystocentryczny, a tym samym trynitarzy, wymiar tej modlitwy wskazuje na jej centralne miejsce obok Eucharystii. ${ }^{76}$ Prawdę tę odzwierciedla wyjaśnienie natury tejże modlitwy zawarte w Wprowadzeniu, odwołujące się do św. Augustyna: „On sam się modli za nas i w nas, a i do Niego my się modlimy. On modli się za nas jako nasz kapłan; modli się w nas, bo jest Głową Ciała, którym jesteśmy, a modlimy się do Niego, bo jest naszym Bogiem. Rozpoznajemy więc w Nim nasze głosy, a Jego głos w nas samych". ${ }^{77}$ To bardzo klarowne ujęcie wspólnotowości tej modlitwy, która urzeczywistnia się w relacji między Chrystusem oraz modlącym się Kościołem i poszczególnymi jego członkami. Należy także podkreślić jej charakter biblijny w odsłaniającym się misterium communio wspólnotowego przez doświadczenie Słowa w słowie oraz inspirację Ducha Świętego (por. Ga 4, 6; Rz 8, 26-27). Tę wspólnotowość w sposób bezpośredni podkreśla Kościół w swoim nauczaniu: „Jest ona «publiczną modlitwą Kościoła», w której wierni

74 KKK 1174; D. W i d e r, Zawsze się módlcie, s. 90.

75 KL 84.

76 Por. KKK 1178; B. M o k r z y c k i, Kościół w świętości, Warszawa 1984, s. 257; M. K u n z e r, Liturgia Kościoła, tłum. L. B a 1 t e r, Poznań 1999, s. 520; B. N a d o 1 s k i, Liturgika. Liturgia i czas, t. II, Poznań 1991, s. 241-242.

77 Ogólne Wprowadzenie do Liturgii Godzin, Liturgia Godzin, t. I, Poznań 1982, 7; Z. N a b z d y k, Modlitwa, s. 127-128; A. Z u b e r b i e r, Korzenie i natura modlitwy chrześcijan, s. 41-43. 
(duchowni, zakonnicy, zakonnice i świeccy) sprawują królewskie kapłaństwo ochrzczonych. Liturgia Godzin celebrowana «według formy zatwierdzonej» przez Kościół" ${ }^{78}$ Dokonuje się w niej zatem zbawczy dialog, który przestaje być jedynie prywatnym aktem chrześcijanina. Jest to modlitwa, która dokonuje się w Kościele, dzięki Kościołowi i w imieniu Kościoła. ${ }^{79}$ Aspekt ten ma niezwykle ważne konsekwencje, ponieważ owoce, jak i skutki modlitwy Liturgią Godzin dotyczą całego, Kościoła, a także konkretnych wspólnot partykularnych. W niej znajduje chrześcijanin wzór doskonałej modlitwy. Ogólne Wrowadzenie do Liturgii Godzin, odwołując się do Pisma Świętego, wskazuje, że winna to być modlitwa wynikająca z konieczności, czyli z poczucia odpowiedzialności za łaskę, jaką jest cały Kościół. Następne jej cechy to: pokora, czujność, ustawiczność, ufność. Powinna wynikać z dobrej intencji przenikniętej świadomością miłości oraz szacunku wobec Boga i wówczas autentycznie przyjmuje ona formy modlitwy uwielbienia, dziękczynienia, prośby oraz wstawiennictwa. ${ }^{80}$ Są to cechy modlitwy doskonałej, która jest skuteczna, uświęcając cały Kościół i samego modlącego się. Ze swej natury łączy ona wspólnotowość oraz indywidualność. Skuteczność tej modlitwy liturgicznej, włączonej w całość liturgii Kościoła. wynika zatem z ex opere operantis Ecclesiae. ${ }^{81}$ Idąc za nauką II Soboru Watykańskiego, stwierdzamy, że jej komuniotwórczy charakter dotyka całego Kościoła a także poszczególnych modlących się wspólnot. Szczególnie przypisana jest tym osobom, które z racji swojego powołania do życia konsekrowanego oraz kapłańskiego, we wspólnotach zobowiązane są do modlitwy wspólnej. Taki sposób życia poświęconego modlitwie jest darem dla całego Kościoła i jego dzieła apostolskiego. ${ }^{82} \mathrm{Nie}$

78 KKK 1174.

79 Por. KK 24, 41; KL 86; A. C e n c i n i, Oddech życia. Easka formacji permanentnej, tłum. J. Z a r z y c k a, Kraków 2003, s. 111; B. M o k r z y c k i, Kościót wświętości, s. 257-258.

${ }^{80}$ Ogólne Wprowadzenie do Liturgii Godzin, 5; M. K u n z l e r, Liturgia Kościoła, s. 520-524.

${ }_{81}$ Por. S. U r b a ń s k i, Teologia modlitwy, s. 252.

82 Por. KL 95; Ogólne Wprowadzenie do Liturgii Godzin, 2, 25. 
powinna ona być także obca osobom świeckim, którzy rozwijają swoje życie duchowe na drodze formacji w ramach ruchu bądź stowarzyszenia. Ojcowie Soboru zalecają, aby w tę modlitwę włączać wspólnotę parafialną: „Duszpasterze niech się starają w niedziele i uroczyste święta celebrować w kościołach z udziałem wiernych główne godziny, zwłaszcza nieszpory. Zaleca się, aby i świeccy recytowali liturgię godzin czy to z kapłanami, czy na swoich zebraniach, czy nawet indywidualnie". ${ }^{83}$

Teologowie, dokonując kategoryzacji modlitwy, stwierdzają, że w ramach modlitwy wspólnotowej, oprócz modlitwy liturgicznej należy uwzględnić pozaliturgiczną, określaną niekiedy jako paraliturgiczną, która może przybierać charakter sprawowanej indywidualnie lub też wspólnie. ${ }^{84} \mathrm{~W}$ tym zagadnieniu interesuje nas przede wszystkim ten drugi jej wymiar. Wspólne sprawowanie i przeżywanie tego rodzaju modlitwy wiąże się z całą różnorodnością nabożeństw, liturgii słowa, wspólną medytacją, praktykowaniem lectio divina. Odsłania się w tym względzie niezwykła działanie Ducha Świętego i bogactwo Kościoła. Mamy tu do czynienia z szeroko rozumianą tradycją poszczególnych Kościołów lokalnych zakorzenionych i żyjących w tradycji narodu czy też kontynentu. Bez wątpienia w sposób najbardziej klarowny ten charakter modlitwy związany jest w sposób bezpośredni z grupami formacji kapłańskiej, życia konsekrowanego ${ }^{85}$ a także laikatu. ${ }^{86}$

83 KL 100; DZ 7; Ogólne Wprowadzenie do Liturgii Godzin, 27; J a n P a w eł II, Adhortacja apostolska Novo Millenio ineunte, Rzym 6 I 2001, nr 34.

${ }_{84}$ Por. S. U r b a ń s k i, Teologia modlitwy, s. 266-267; S. W i te k, Teologia życia duchowego, s. 288.

85 Por. tamże.

${ }^{86}$ Por. Ja n P aw e ł II, Adhortacja apostolska Christifideles laici, Rzym 30 XII 1988, nr 16. W swoim nauczaniu papież stwierdza bardzo jednoznacznie, wskazując na charakter modlitwy liturgicznej i paraliturgicznej w życiu uświecającym świeckich: „Życie wedle Ducha, które wydaje owoc uświęcenia (por. Rz 6, 22; Ga 5, 22), pobudza ochrzczonych i wymaga od nich wszystkich razem i każdego z osobna tego, by naśladując Jezusa Chrystusa przyjęli Jego Błogosławieństwa, słuchali i rozważali słowa Boże, świadomie i aktywnie uczestniczyli w liturgicznym i sakramentalnym życiu Kościoła, pamiętali o osobistej, rodzinnej i wspólnotowej 
Modlitwa wspólna, jak to zostało już zaznaczone, ma szczególne znaczenie i wyraża zgodne zwrócenie modlących się ku Bogu, który jest zasadą ale także racją tego aktu. To On swoją łaską, przez działanie Ducha Świętego, inicjuje i konstytuuje wspólnotę (por. Mt 18, 19; Rz 12, 4-8). Oznacza to, że jakość życia modlących się wspólnie znajduje swoje odniesienie do Boga. Zasadniczym czynnikiem komuniotwórczym staje się miłość do Boga przenoszona na poziom relacji międzyludzkich (por. Mk 12, 28b-34;1J 4, 7-12), budując rzeczywistą jedność. Dla św. Wincentego Pallotiego właśnie miłość jest fundamentem każdego działania i racją każdej inicjatywy chrześcijanina i z tego względu szczególnie cenił sobie 13. rozdział Pierwszego Listu do Koryntian. ${ }^{87}$ Idąc zaś za analizą podjętą przez ks. Z. Nabzdyka, stwierdzamy, że ten rodzaj modlitwy, pod względem antropologicznym, pozwala człowiekowi wyjść poza ramy swojej indywidualności. Dotyczy to zarówno samej formy, jak również intencji i jej ukierunkowania ${ }^{88}$ Oznacza to, że rozwój autentycznej pobożności dokonuje się jednocześnie na dwóch poziomach: indywidualnym oraz wspólnotowym. Będąc wobec siebie łączne, uzupełniające się oraz komplementarne, sprawiają, że życie modlitewne chrześcijanina może się rozwijać w sposób prawidłowy i jest mniej podatne na skrzywienia oraz dewiacje w tym względzie. W ten sposób wzrasta skuteczność modlitwy o charakterze nadprzyrodzonym, jak to podkreśla św. Tomasz z A kwinu, ${ }^{89}$ ale jednocześnie staje się ona żywym

modlitwie, byli głodni i spragnieni sprawiedliwości, praktykowali miłość we wszystkich sytuacjach życiowych i by służyli braciom, zwłaszcza najmniejszym, ubogim i cierpiącym”. KKK 901.

${ }^{87}$ Por. J. S t a b i ń s k a, Wincenty Pallotti, s. 85. Autorka, analizując rozumienie miłości u św. Wincentego Pallottiego, podkreśla jej następujące aspekty: nieskończona miłość Boga, którą porównywał do palącego ognia; miłość udzielająca się, która przede wszystkim odsłania się w stworzeniu i wcieleniu; miłość miłosierna - miłość miłosierna udziela się w stworzeniu, odkupieniu i uświęceniu, która domaga się od człowieka uznania swojej nędzy; por. tamże, s. 156-161.

${ }^{88}$ Por. Z. N a b z d y k, Modlitwa-źródto i wyraz duchowości, s. 133.

${ }^{89}$ Por. Św. Tomas z z A kw in u, STh II-II, q 83, a. 7. 
świadectwem i właściwą odpowiedzią wobec współczesnych trendów sekularystycznych, kontynuując dzieło Boga przez cosecratio mundi..$^{90}$

$$
* * *
$$

Modlitwa chrześcijanina jest przedmiotem jego codziennej troski w procesie rozwoju życia duchowego. Możemy stwierdzić, że bez niej i jej dynamicznego rozwoju niemożliwy jest rozwój duchowy chrześcijanina, a także Kościoła, w którym żyje. Jest ona także bardzo rozległym przedmiotem pracy naukowo-badawczej na gruncie teologii, a szczególnie teologii duchowości. Wówczas musi być potraktowana wieloaspektowo oraz wielokierunkowo. Pośród całego zróżnicowania i kategorii modlitw bardzo istotną jest modlitwa wspólnotowa oraz modlitwa wspólnoty. To rozróżnienie jest konieczne, ponieważ odsłania nam prawdę, że każda modlitwa ma charakter wspólnotowy, ale nie zawsze jest ona wspólna. Jednakże wspólnie sprawowana modlitwa jest źródłem życia chrześcijanina, Kościoła a także najbardziej jasnym i czytelnym świadectwem wiary.

ks. Marek TATAR

Słowa kluczowe: modlitwa; wspólnota; liturgia; formacja; duchowość

Keywords: prayer; community; liturgy; formation; spirituality

\section{The Common and Community-Creative Character of Prayer Summary}

The prayer of a Christian is the subject of his daily care in the process of spiritual development. We can say that without it and its dynamic development it is not possible for the spiritual progress of the Christian and the Church in which he or she lives. It is also a very extensive subject of research and scientific work in the field of theology and especially the theology of spirituality. Hence, it must be treated in a multi-faceted and multi-directional way. Among all the different categories of prayer, community prayer and

90 Por. KK 1. 
common prayer are very important. This distinction is necessary because it reveals to us the truth that every prayer has a communal character, but it is not always common. However, prayer celebrated together is the source of Christian life and the Church, and it is the clearest and most readable testimony of faith. 